Apidologie, 1970, 1 (4), 351-373.

\title{
ANATOMY AND HISTOLOGY OF THE GENITAL TRACT, SPERMATHECA, SPERMATHECAL DUCT AND GLANDS OF APIS MELLIFICA QUEENS (HYMENOPTERA : APIDAE) ${ }^{1}$
}

\author{
João M. F. DE CAMARGO and M. L. S. MELLO \\ Departamento de Genética \\ Faculdade de Medicina, Ribeirão Preto, S.P., Brasil
}

SUMMARY

The genital chamber, the spermatheca and the spermathecal duct and glands were studied by classical methods of common light and phase microscopy. Some histochemical reactions were also employed. Results were compared with published data.

1. The whole genital chamber and the valve-fold have a single cuboidal epithelium with a plurilamellar and chitinous cuticle. The cells of the genital chamber and valve-fold epithelium have irregular and darkly stained nuclei, with many chromatin granules. The cytoplasm is vacuolized and secretion is stored in vacuoles which burst out of the apical portions of the cells.

2. Sense organs were not found in the valve-fold or other parts of the genital chamber.

3. The spermatheca has a single epithelium, columnar in pupae and cuboidal in both virgin and mated queens. The cell nucleus of mated queens is mesially located in the cell and has a pycnotic character. The cytoplasm always reacts for protein. There are no secretory vacuoles in the spermathecal epithelium.

1. This research was supported by FG-Br-102, United States Department of Agriculture, P.L. 480; and Fundação de Amparo à Pesquisa do Estado de São Paulo - Brasil. 
4. The spermathecal glands have a single secretery epithelium and an intima. The epithelium lies on an acidophilic basal membrane with fusiform nuclei. The cytoplasm is basophilic and reacts for protein and the nuclei are large, spherical and of basal distribution in virgin queens. Secretion is stored in large vacuoles in mated queens epithelium, and the nuclei are also basally located. Intracytoplasmic canaliculi collect secretion and drain it to the gland lumen; these canaliculi react to PAS. The intima is an amorphous cytoplasmic mass with pycnotic nuclei in a degenerative process.

Two layers of cells and partially developed collectory canaliculi are found in 7 days-old pupae.

5. The " sperm pump " has long and compressed epithelial cells. There is a thick and basophilic cuticle which reacts for polysaccharides. The nuclei are small and discoidal.

Unlike the spermatheca, the duct has secretion of proteic globules.

\section{1. - INTRODUCTION}

The genital tract of Apis mellifica queens has been the subject of many studies, but many anatomical aspects of the queen's genital apparatus are not well known, in spite of insemination techniques being applied with success.

Swammerdan (1758), Hunter (1792), Cheshire (1884), Bresslau (1905) and Adam (1913), among others, were the pioneers in this field. The instruments for artificial insemination were improved by WATSON (1927), Nolan $(1932,1937)$, Laidlaw (1944) and Mackensen \& Roberts (1948). Laidlaw (1944) has studied the reproductive organs of Apis mellifica queens. Kapil (1962), Fyg (1966), Woyke et al. (1966), Fresnaye (1966) and others have published new data about anatomy and insemination techniques. Lately, some modifications of the classical insemination techniques were presented. KERR (1958 - personal communication) adds to the water of the insemination needle $1 \%$ streptomycin as a preventive against infection. Camargo \& Gonçalves (1968) have introduced a new method by staining the outer genital structures of the queens with Fast Green in such a way that visualization of the valve-fold becomes less difficult and its handling can safely be done. WOYKE (1967) has brought out the significance of spermathecal volume and has advised the use of queens weighting more than $230 \mathrm{mg}$.

In this paper we present detailed information about anatomy and histology of the tract, mainly through more detailed illustrations. We also describe the spermathecal duct and glands and the spermatheca.

\section{2. - MATERIALS AND METHODS}

Virgin and mated queen bees, Apis mellifica adansonii, Apis mellifica caucasica and Apis mellifica ligustica and 7-days-old pupae of Apis mellifica adansonii were used. The adansorii queens were hybrid individuals, with most of the chàracters of their pure African ancestors.

The general morphology of the genital tract, spermatheca and spermathecal glands was studied through dissection of live bees in physiological saline, under a binocular microscope.

For histological examination the organs were fixed in Bouin's or Dietrich's fixative for 18-24 hours, embedded in paraffin, sectioned at $8 \mu$ (complete serial sections) and stained with haematoxylin-eosin.

The organs of the pupae were histologically investigated and compared with the same ones of the adults. 
Whole spermathecal glands were squashed, stained with $1 \%$ acetic carmin or methylblue for a better examination of the structure of their canaliculi.

For investigation of protein components, the material was fixed in Baker's calcium-formaline (PEARse, 1961), embedded in paraffin, and the sections were stained by Ninhydrin-Schiff (Yasuma and Itchikawa, 1953 - apud Pearse, 1961).

Sections fixed in Bouin's were also submitted to PAS reactions (Pearse, 1961).

The genital tract was also fixed in Aoyama and impregnated by silver (PEARSE, 1961) to look for sense organs.

All drawings were made with the aid of a Wild camera lucida.

\section{3 - RESULTS}

\section{1. - Genital tract. General aspects (fig. 1, 2, 3 and 4)}

The genital tract of Apis mellifica queens is in the cavity of the adbomen on the inner anterior surface of sternum VII, and the copulatory portion opens into the sting chamber (fig. 1, 2 and 3). According to classical designations, the structure consists of a bursa copulatrix, lateral pouches of the bursa copulatrix, genital chamber, valve-fold and median and lateral oviducts; the spermatheca or sperm pouch is an accessory structure. The copulatory portion proper is the bursa copulatrix (fig. 1,2 and 3); it is a broad triangular cavity which develops from a heavy fold of the genital membrane at the base of the sting chamber (fig. 1,

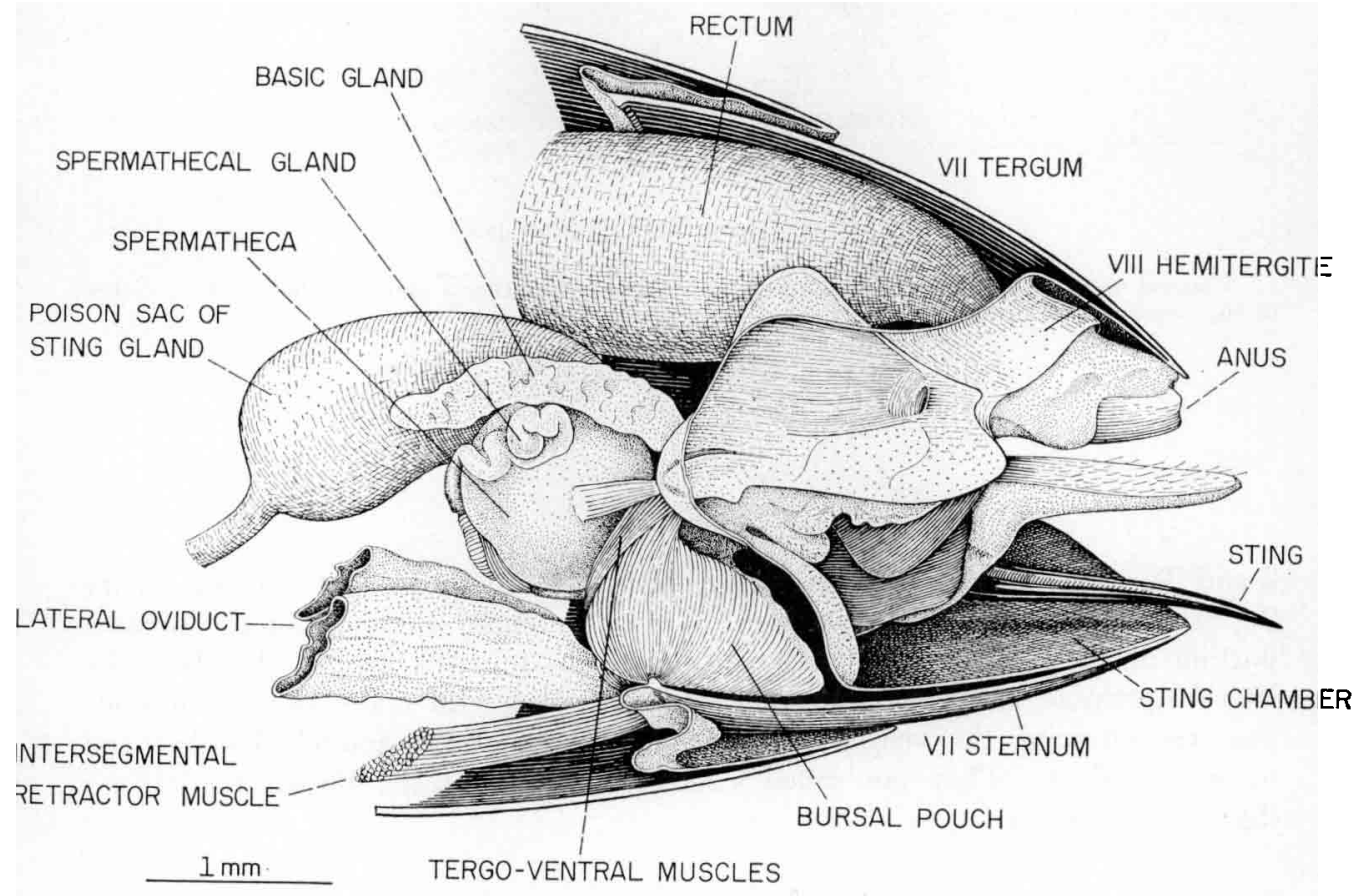

Fig. 1. - Apis mellifica ligustica queen

Lateral view of the genital tract, sting and related structures. 


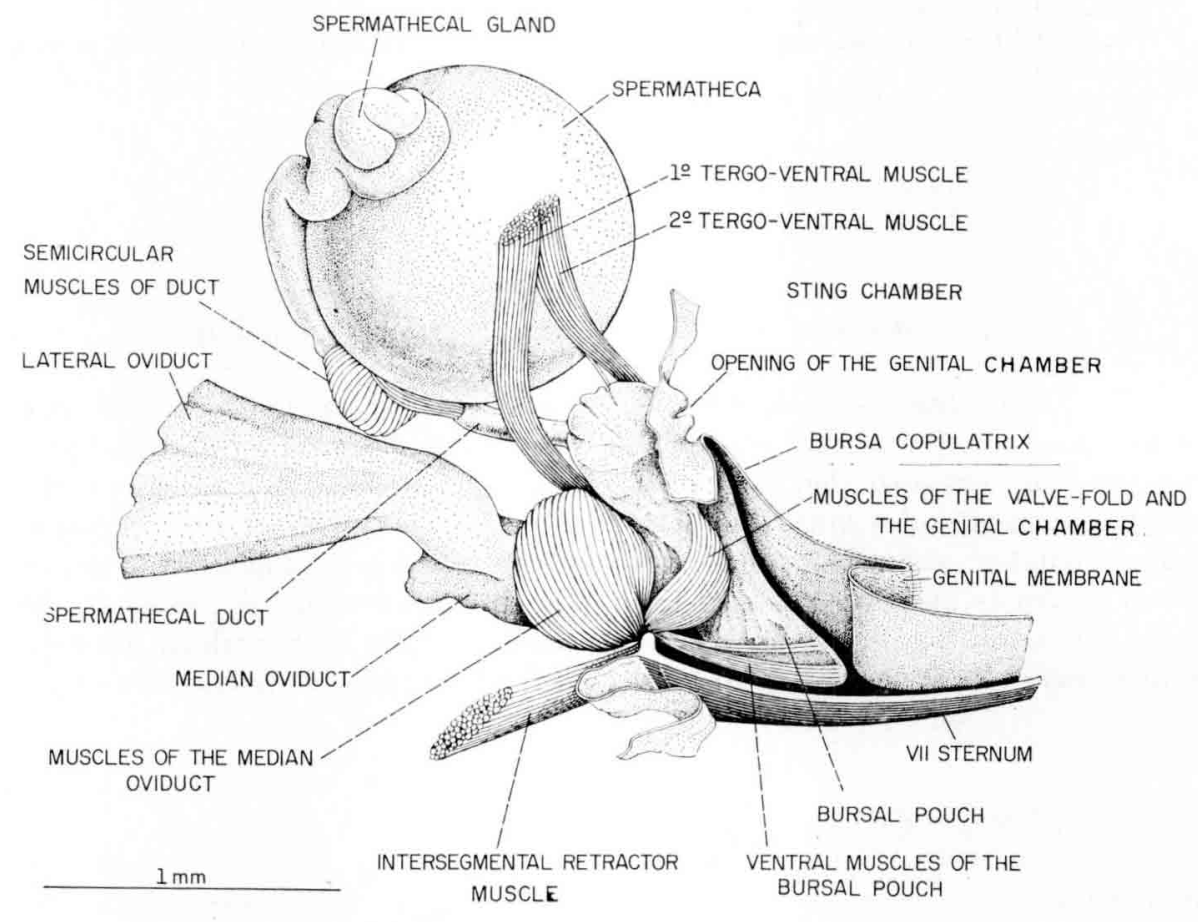

Fig. 2. - Apis mellifica ligustica queen

Lateral view of the genital tract, spermatheca and spermathecal glands. One of the pouches of the bursa was omitted.

2 and 3). The sting base, in a resting stage, is perfectly packed into this cavity (fig. 1), covering the tract openings. There are three openings in the median portion of the bursa. The median orifice opens into the genital chamber; the lateral openings which surround the first one, widen to make two voluminous pouches, covering the ventral and lateral surfaces of the genital chamber and median oviduct. They are called "lateral pouches of the bursa copulatrix " (fig. 1,2, 3 and 4). 


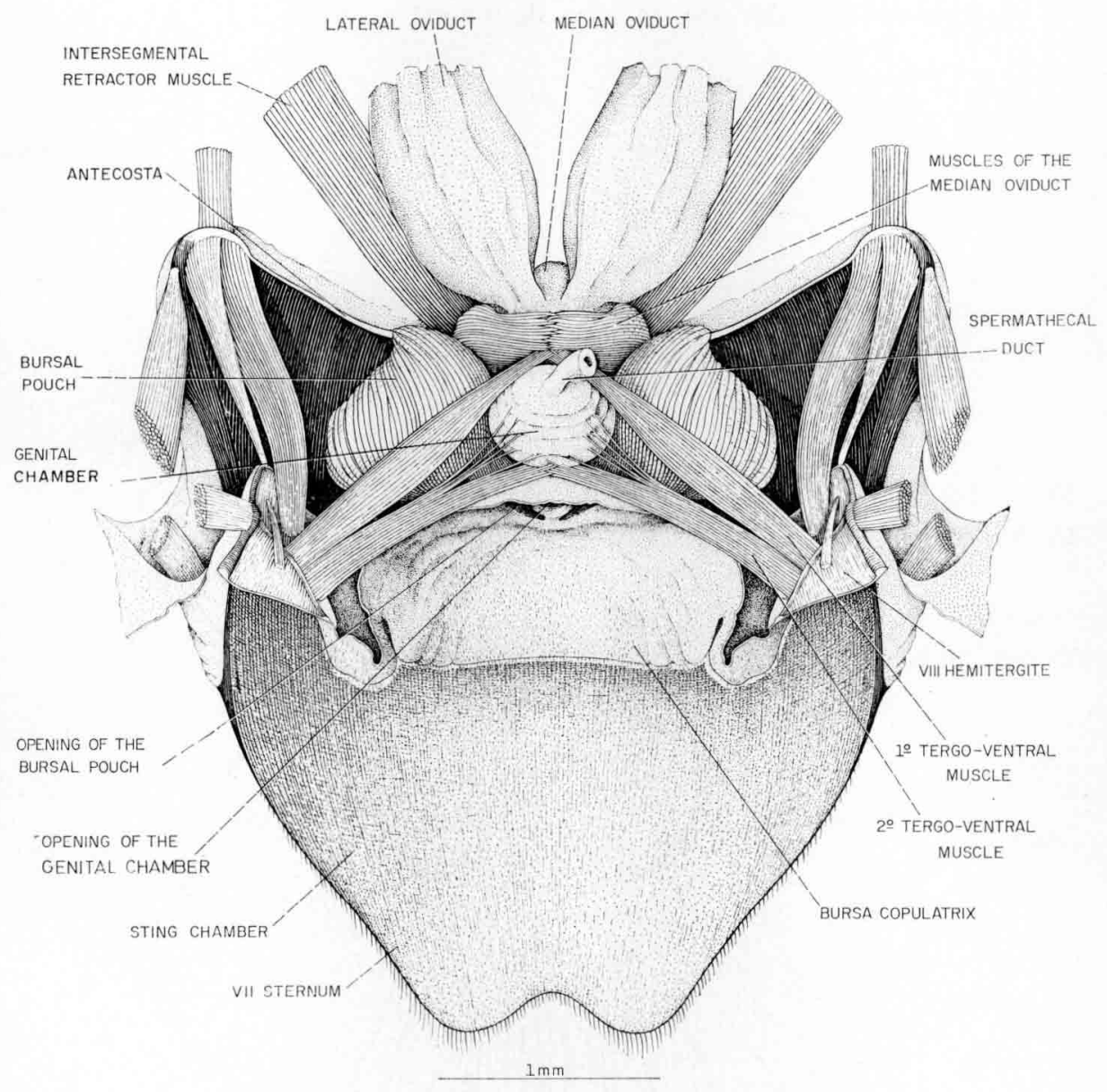

Fig. 3. - Apis mellifica ligustica queen

Dorsal view of the genital tract and its musculature. The spermatheca was omitted. 
The median orifice abruptly enlarges anteriorly, becoming a chamber which is called the genital chamber (= vagina). This structure is anteriorly limited by a strong ventral epithelial fold, i. e., the valve-fold, and by the spermathecal duct opening. After the valve-fold is the median oviduct; together with the genital chamber it constitutes a single channel, interrupted only by the valve-fold. The median oviduct bifurcates to form the lateral oviducts.

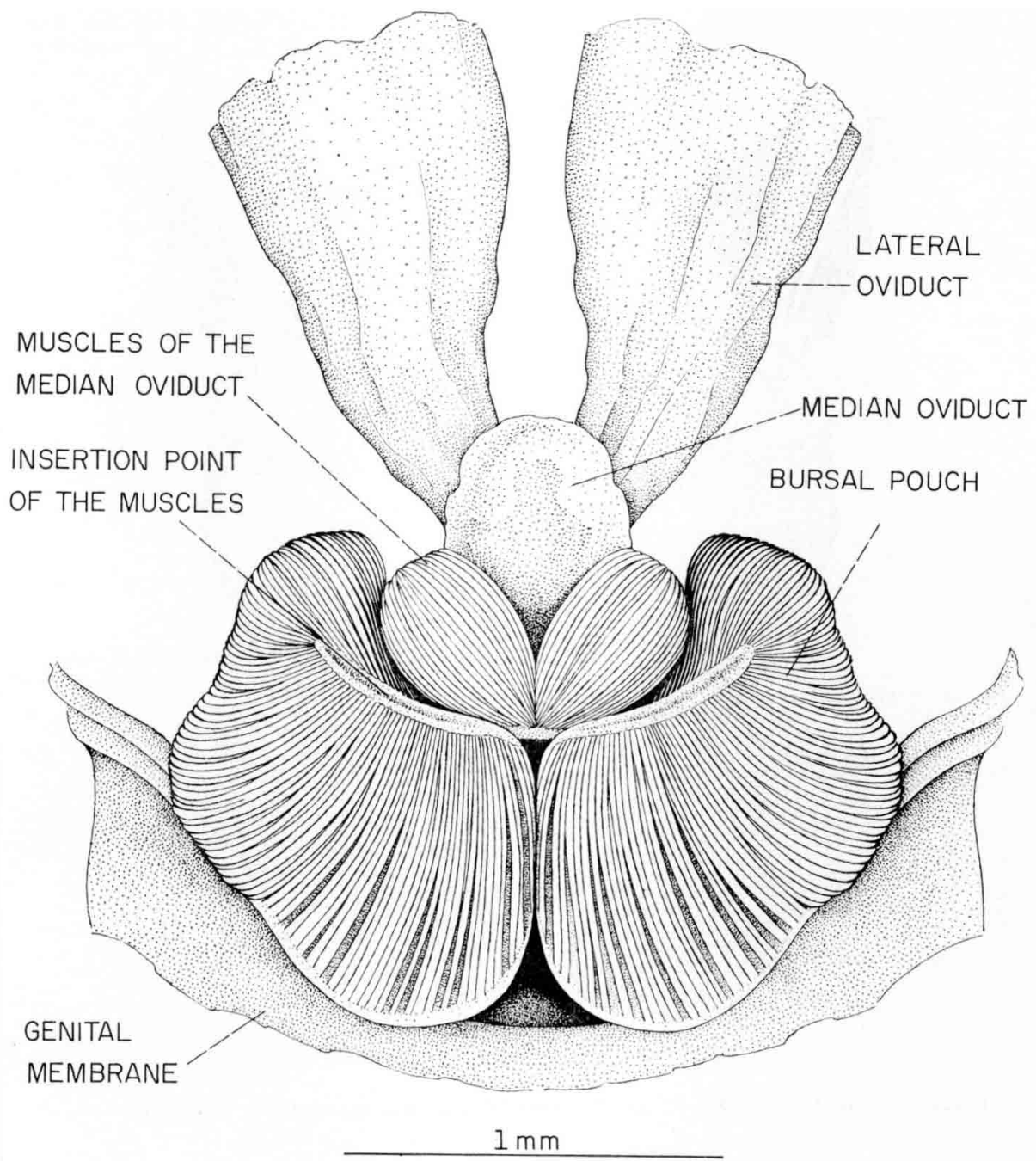

Fig. 4. - Apis mellifica ligustica queen

Ventral view of the genital tract. The muscles attach in the antecosta of the sternum VII. Here the antecosta was omitted. 


\section{2. - Genital chamber and valve-fold (fig. 2, 3, 5, 6, 7 and 8)}

The genital chamber and related structures have an epithelium wich develops from the invaginated genital membrane, thus being of ectodermal origin.

The receptacular orifice of the genital chamber in the bursa copulatrix is a flattened slit surrounded by the lateral pouch openings (fig. 3, 5 and 6). The genital chamber turns anteriorly downwards and its surface has several folds which distend when an egg is passing through. Above it is supplied with fibers of the 2nd. tergo-ventral muscules (fig. 2 and 3 ) and ventrally by muscular fibers which originate in the median antecosta of sternum VII (fig. 5).

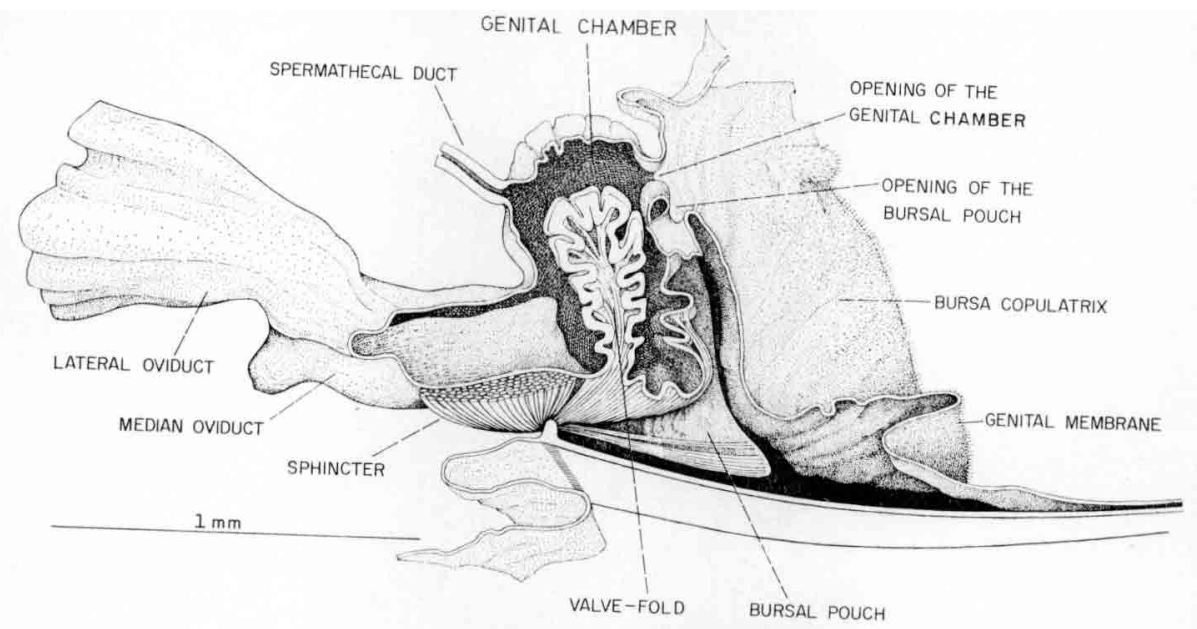

Fig. 5. - Apis mellifica ligustica queen

Longitudinal section of the genital tract, showing the valve-fold situation.

Histologically it consists of a single cuboidal epithelium with a plurilamelar cuticle. The cuticle is divided into three layers according to affinity to the histological stains (haematoxylin-eosin). The epicuticle, closest to the lumen, is a

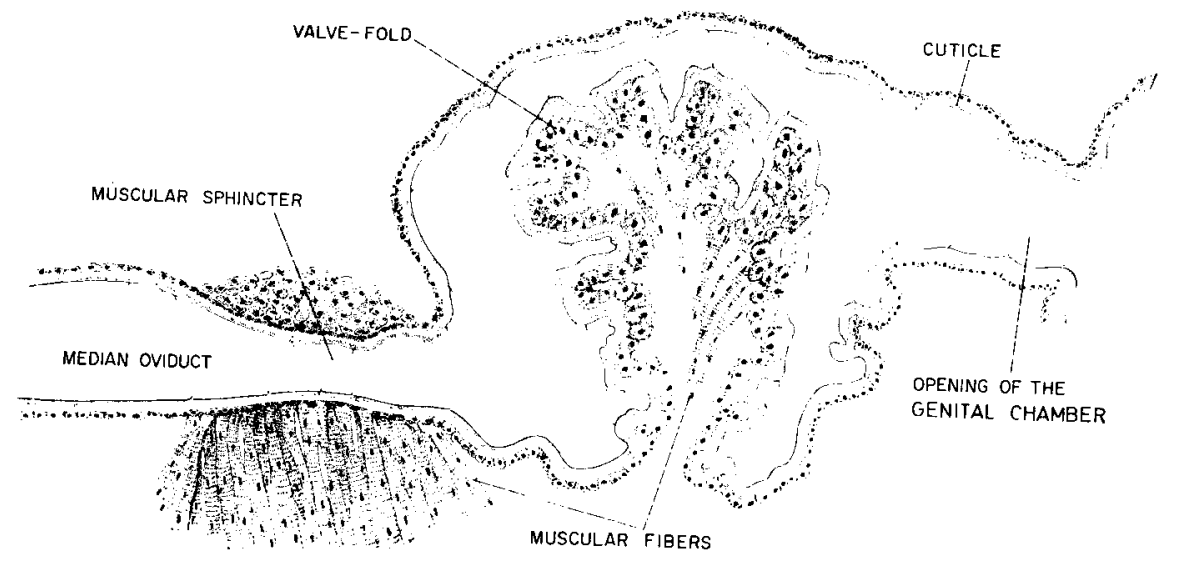

Fic. 6. - Apis mellifica adansonii and ligustica queens

Longitudinal section of the genital tract. 
thin and acidophilic layer; it reacts with PAS strongly only in virgin queens. The exocuticle is a densely basophilic layer and the endocuticle is the thickest layer, in contact with the receptacular epithelium. Few short spine-like structures occur in the cuticle of this portion of the tract, contrasting with the median oviduct (fig. 6). The epithelial cells of the genital chamber have irregular and dark stained nuclei in which chromatin granules are easily detectable. The cytoplasm is vacuolated, suggesting a secretory function (fig. 6, 7 and 8). Secretion is stored in vacuoles which burst in the apical parts of the cells; in our preparations it was " washed " by the fixatives.

The genital chamber in early pupae is already differentiated, but its cuticle is thin and translucent.

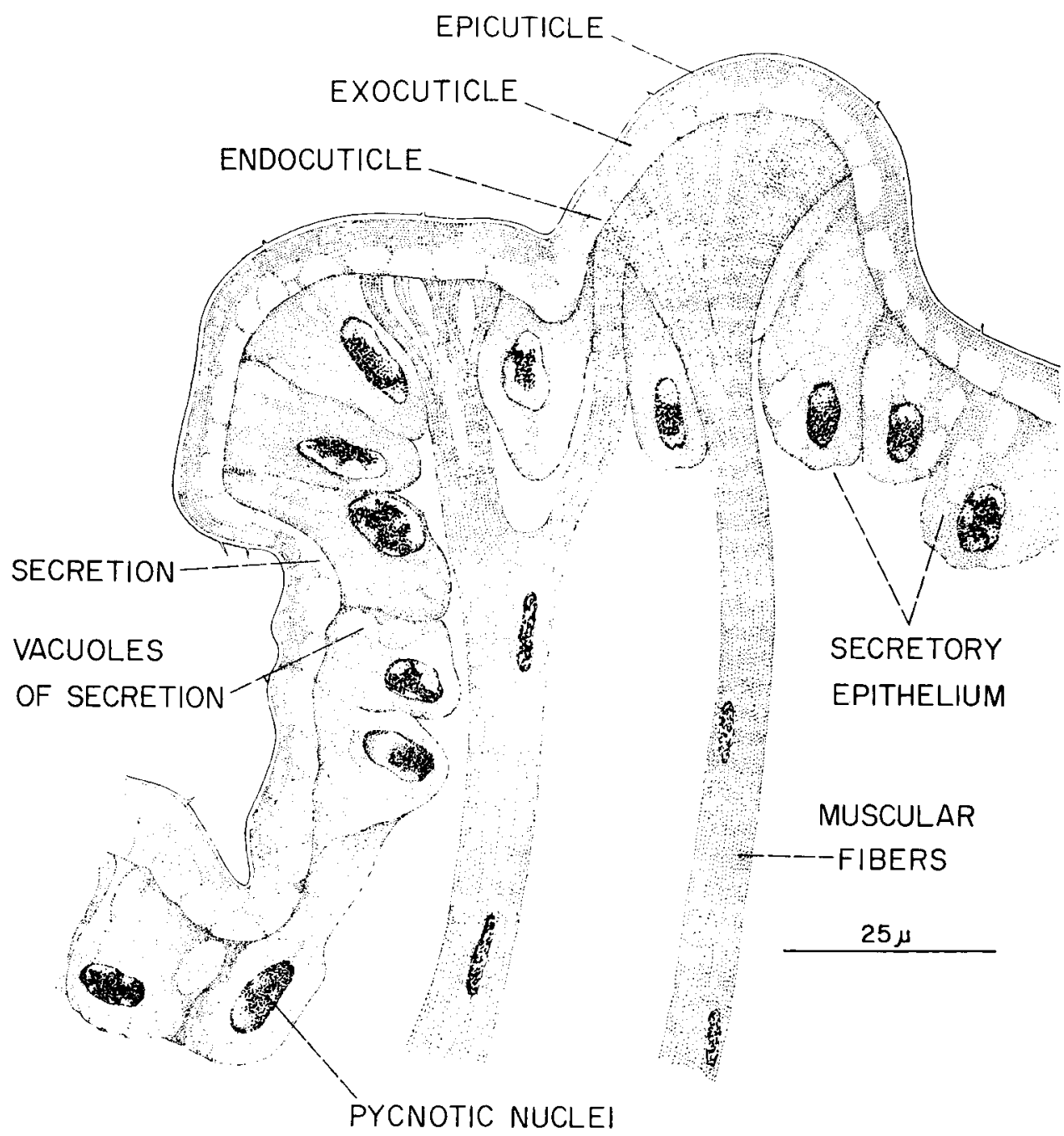

Fig. 7. - Apis mellifica adansonii and ligustica queens

Histological detail of the valve-fold, showing the muscles attachment. 

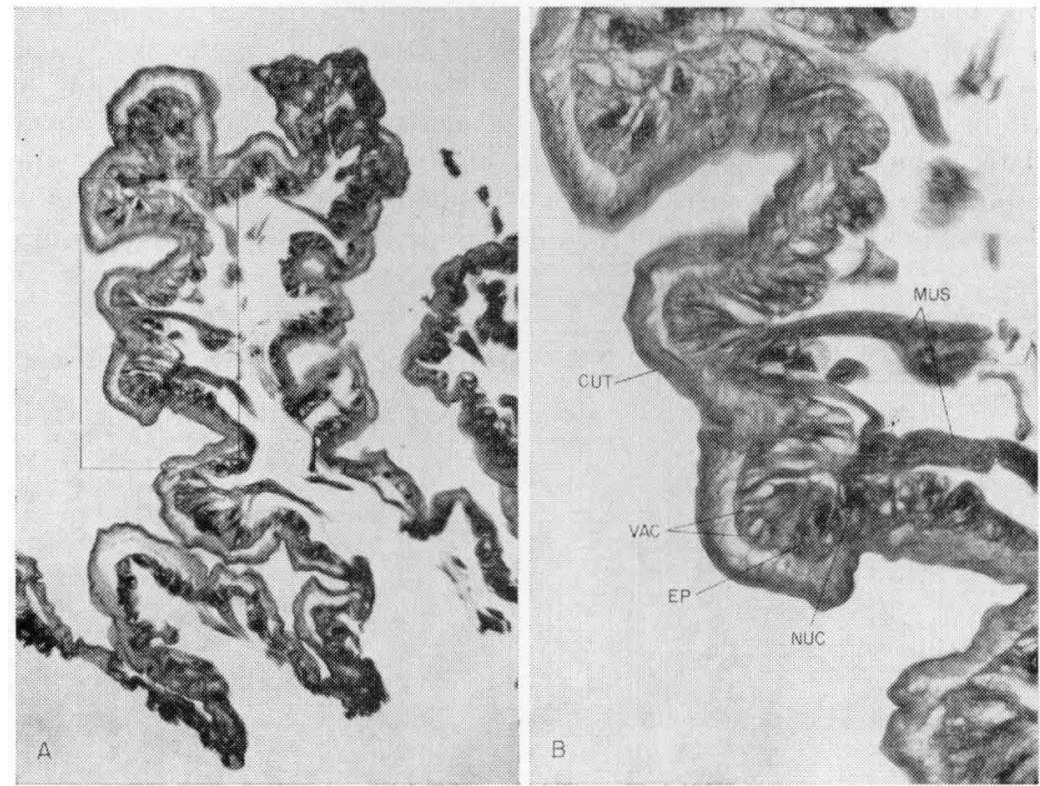

Fic. 8. - Apis mellifica adansonii and ligustica queens

Histological sections of the valve-fold.

A. General view; B. Details.

$$
\begin{array}{ll}
\text { MUS }=\text { Muscles } & \text { NUC }=\text { Nucleus } \\
\text { CUT }=\text { Cuticle } & \text { VAC }=\text { Vacuoles } \\
\text { EP }=\text { Epithelium } &
\end{array}
$$

The valve-fold epithelial cells are also secretory, but the cuticle is thin and ridged. There is a musculature which protrudes among the secretory epithelial cells of the valve-fold and reaches the cuticle. These muscles attach on the median antecosta of sternum VII.

Search for sense organs in the genital chamber and specially in the valvefold was negative.

\section{3. - Median and lateral oviducts}

Anterior to the valve-fold is the median oviduct, extending to the lateral oviducts. This structure has a heavily longitudinal invagination in addition to two lateral folds on the ventral surface and is T-shaped in transversal section. Its lumen is not reduced by the large surfaces of the folds.

The folds result from a well-developed sphincter, the origin of which is on the median antecosta of sternum VII, like the other muscles of the tract. The pair of 1st. tergo-ventral muscles is inserted dorsally on the median oviduct.

The large and flattened lateral oviducts have the same configuration as the median oviducts; they are supplied with a longitudinal musculature through almost entire lengths, but it is much reduced. 


\section{4. - Lateral pouches of the bursa copulatrix (fig. 1, 2, 3 and 4)}

Two large pouches are latero-ventral to the genital chamber and the median oviduct (fig. 1, 2, 3 and 4). They are invaginations of the genital membrane in the latero-mesial portions of the opening of the genital chamber. The openings of the pouches partially surround the chamber orifice. In upper view, these pouches extend from the genital membrane to the antecosta of sternum VII;
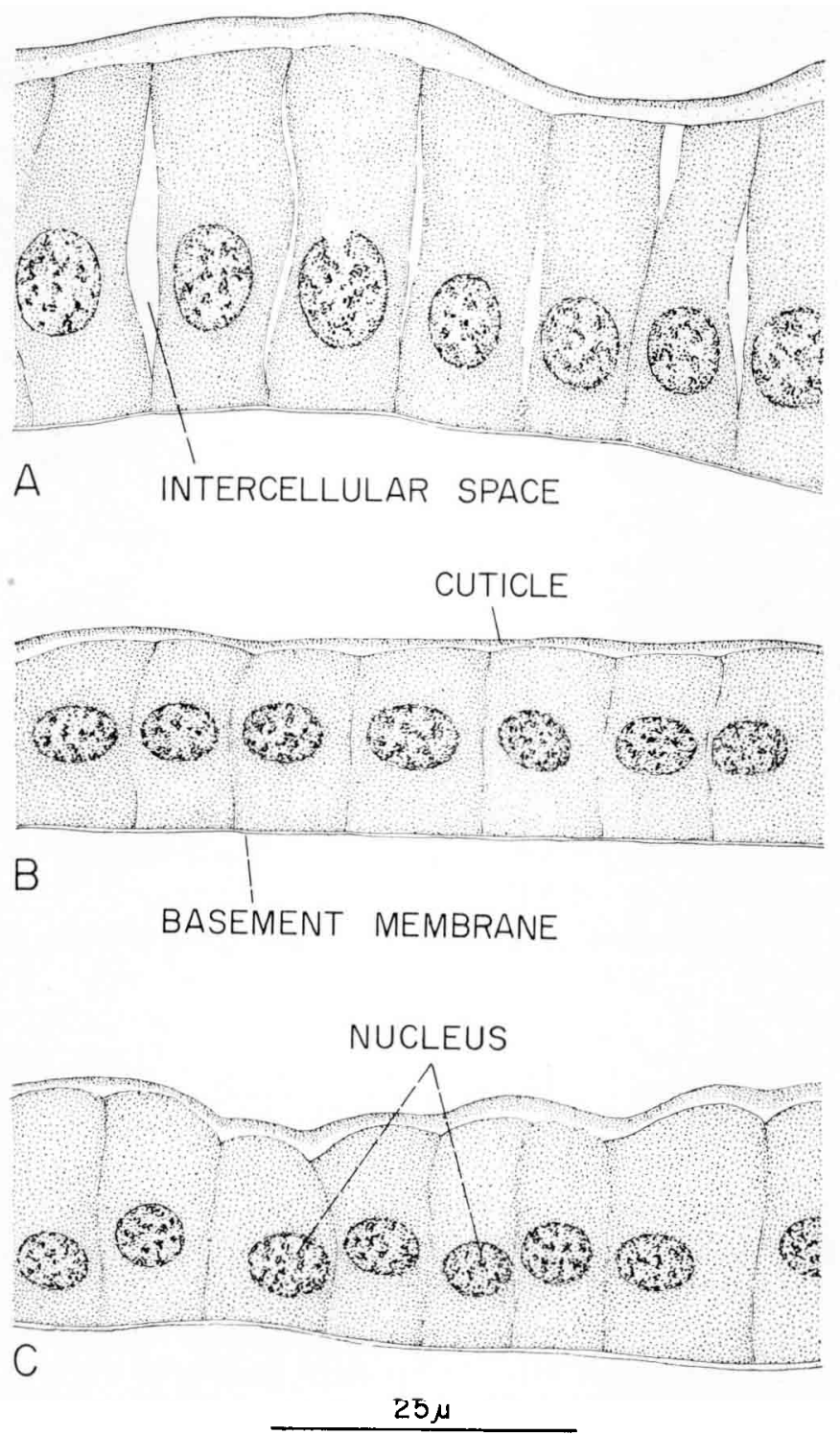

FIc. 9. - Apis mellifica adansonii and ligustica queens

Spermathecal wall.

A. 7 days-old pupa; B. Virgin queen; C. Mated queen. 
their dorsal surface is at the same level as the genital chamber (fig. 3). In lateral view, however, we can see the pouch following the genital membrane as far as the fold which limits the bursa copulatrix (fig. 2). The pouches touch ventrally the whole posterior surface of the antecosta of sternum VII and surround the genital chamber ventrally. The bursa only surrounds the lateral portions of the median oviduct.

The pouch is provided with a heavy longitudinal musculature except for its posterior surface, which follows the genital membrane, and the inner surface which follows the genital chamber in close contact (fig. 1, 2, 3 and 4). These muscles arise from the median part of the antecosta of sternum VII. Each pouch has its own musculature which attaches separatedly (fig. 3 and 4).

This structure has epithelium similar to that already described. This thin epithelium is slender and has some irregular folds.

\section{5. - Spermatheca (fig. 1, 2, 9a, $b$ and $c$ )}

The spherical spermatheca is just above the genital chamber and the median oviduct. It is covered with a dense network of branching tracheae (omitted in all spermathecal drawings) [fig. 1 and 2].

The spermathecal wall consists of a single epithelium, which is columnar in pupal individuals (fig. 9a), cuboidal in virgin and fecundated queens (fig. $9 b$ and c). The pupal epithelial cells have spheric nuclei with a basal distribution. There are distinct intercellular spaces (fig. 9a). Virgin and mated queens have discoidal and mesially located nuclei (fig. $9 b$ and $c$ ), which become pycnotic. The cytoplasm of the spermathecal cells, both in pupae and in adults, reacts to protein test. The epithelium always lies on a thin anucleated basement membrane. A slender and thin cuticle occurs on the spermathecal epithelium. It is more acidophilic in the pupae.

\subsection{1. - Spermathecal glands (fig. $2 ; 10 a, b$ and $c ; 13 a, b, e$ and $f$ )}

The spermathecal glands (one pair) are long and convoluted structures placed just over the latero-anterior spermathecal surface, on the tracheae which surround the spermatheca. These glands unite into a common duct which opens on the antero-ventral midline of the spermatheca. Circular and longitudinal muscles cover the base of the common duct.

The spermathecal glands have a single secretory epithelium and an intima. The epithelium lies on an acidophilic basement membrane which reacts to Ninhydrin-Schiff and in which there are fusiform nuclei. The epithelial cells are columnar in shape. Their cytoplasm, in virgin queens, is homogeneously basophilic and reacts for protein; the nuclei are large, spherical, with many small chromatin granules, and they have a basal distribution in the cells (fig. 10b). The epithelium of mated queens is secretory. Vacuoles store secretion and they are "washed" in our preparations. The cell nuclei are compressed to the basal cellular portion and acquire an ellipsoidal shape (fig. 10c). 


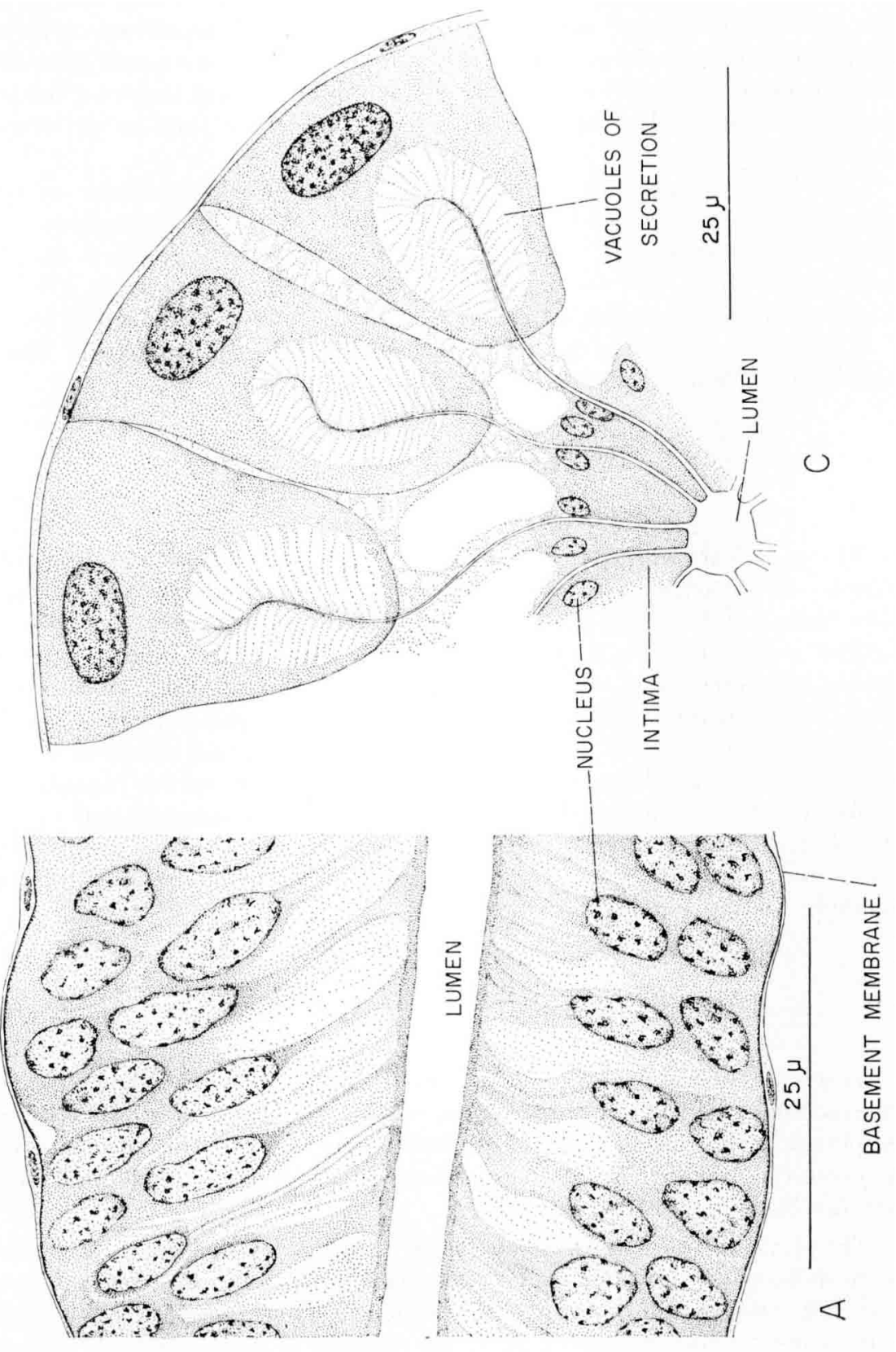

Fig. 10 A, c. - Apis mellifica adansonii and ligustica queens

Histological sections of the spermathecal glands.

A. Longitudinal section of 7 days-old pupae; B. Transversal section of a virgin queen; C. Transversal section of a mated queen. 


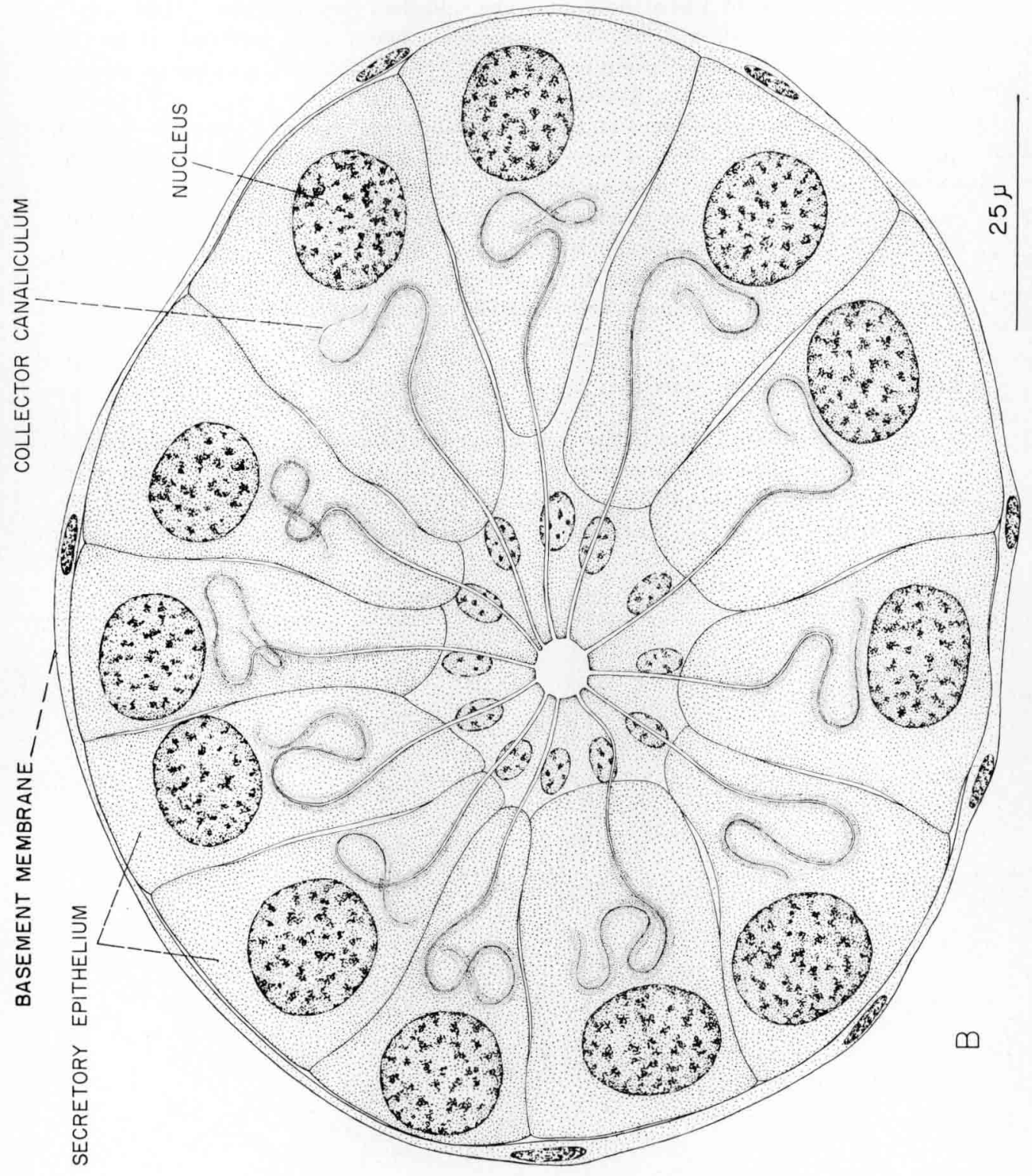

Fig. 10 в 
The glandular secretion stored in vacuoles is collected by cytoplasmic canaliculi, which react with PAS and flow at the glandular lumen. There is one network of canaliculi within each secretory cell of virgin queens (fig. 10b); canaliculi become evident when the glands are squashed (fig. $10 b$ and $c ; 13 e$ and $f$ ). The term intracytoplasmic for the canaliculi is better than intracellular in this case, as this kind of canaliculum is almost always isolated by a plasmic membrane (Cruz-Landim \& Kitajima, 1966).

There is a slender distension in each canaliculum of mated queens. In such queens the canaliculi show several thin, lateral branches closely related to the vacuoles, increasing the collecting surface (fig. 10c).

The intima nuclei are pycnotic and lateral to each collectory canaliculum (fig. $10 b$ and $c$ ). The cytoplasm is amorphous with a darkly basophilic reaction. As the secretory epithelium is not completely differentiated from the intima, in 7 days-old pupae there are two cellular layers and partially developed ducts.

\subsection{2. - Spermathecal duct (fig. 2, 7, 11, 12, 13c and $d$ )}

The spermathecal duct begins just under the base of the spermathecal glands, i. e., in the median antero-ventral surface of the spermatheca. It is posteriorly directed and opens mesially on the dorsal wall of the genital chamber (fig. 2), just over the valve-fold. There is a heavy circular musculature (fig. 7), which



Fic. 11. - Apis mellifica ligustica queen

Transversal section of the sperm pump_where it contacts the spermatheca. 
surrounds it where it is in contact with the spermatheca. A longitudinal musculature occurs in the upper surface of the duct. These muscles have been called " sperm pump ". Where the duct directs to the spermathecal lumen there is the spermathecal glands opening.

Where the spermathecal duct joins the spermatheca, the epithelial cells of the duct are compressed and elongated and the nuclei are small and mesially located (fig. 11, 13c and $d$ ). On the secretory epithelium there is a thick basophilic cuticle which reacts for polysaccharide. Some distance from the spermatheca, the muscles are reduced and in transversal sections the epithelial cells are long and the nuclei discoidal. The cytoplasm is somewhat fibrous in mated queens. There are eosinophilic globules between the epithelial cells and the thick cuticle (fig. 12). These globules react to Ninhydrin-Schiff.

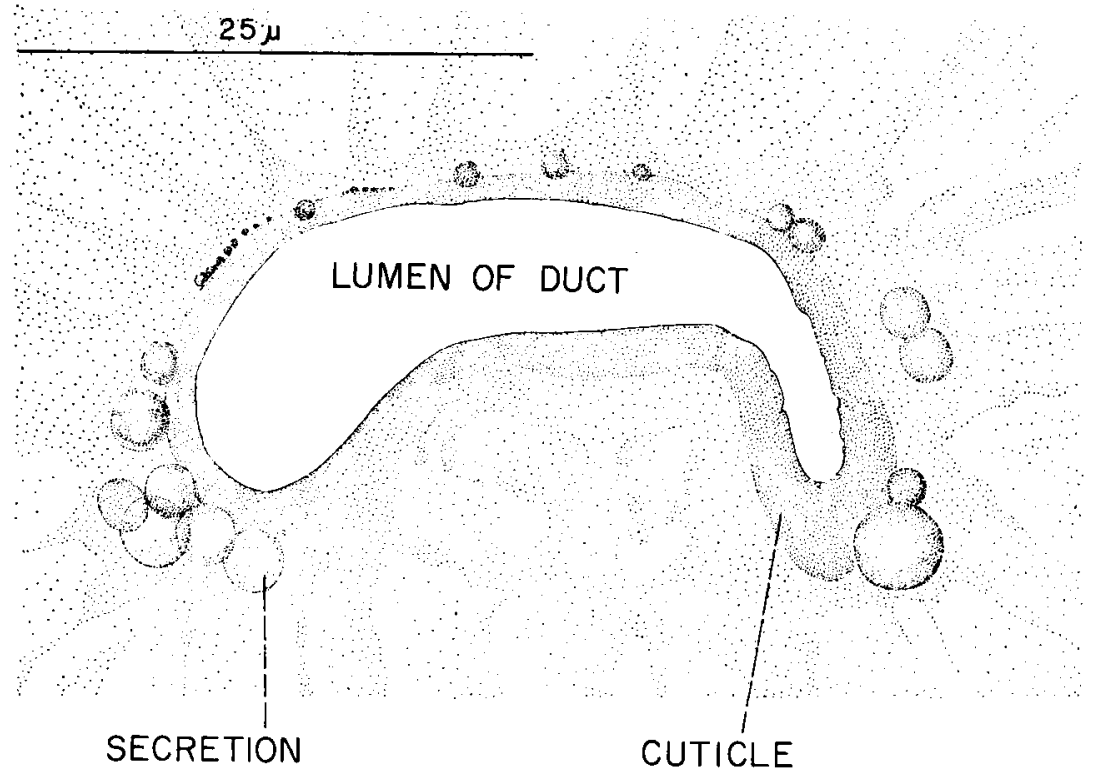

FIg. 12. - Apis mellifica adansonii and ligustica queens

Transversal section of median spermathecal duct. There are some proteic globules between the epitholium and the cuticle.

\section{4. - DISCUSSION AND CONCLUSIONS}

Before discussing the more important points of this paper, we consider the term vagina. This term has been used by several authors (LAIDLAw, 1944; SNodgrass, 1956; KaPIL, 1962; FYg, 1966) and results from an analogy with the genital organs of the mammals. The vagina receives the male organ in mammals, but in the bees the mating sign does not enter the "vagina " except in rare cases (Woyke \& RutTner, 1958). During copulation the mating sign attaches to the lateral pouches of the bursa copulatrix.

We have dissected queens which recently came back from nuptial flight and our 

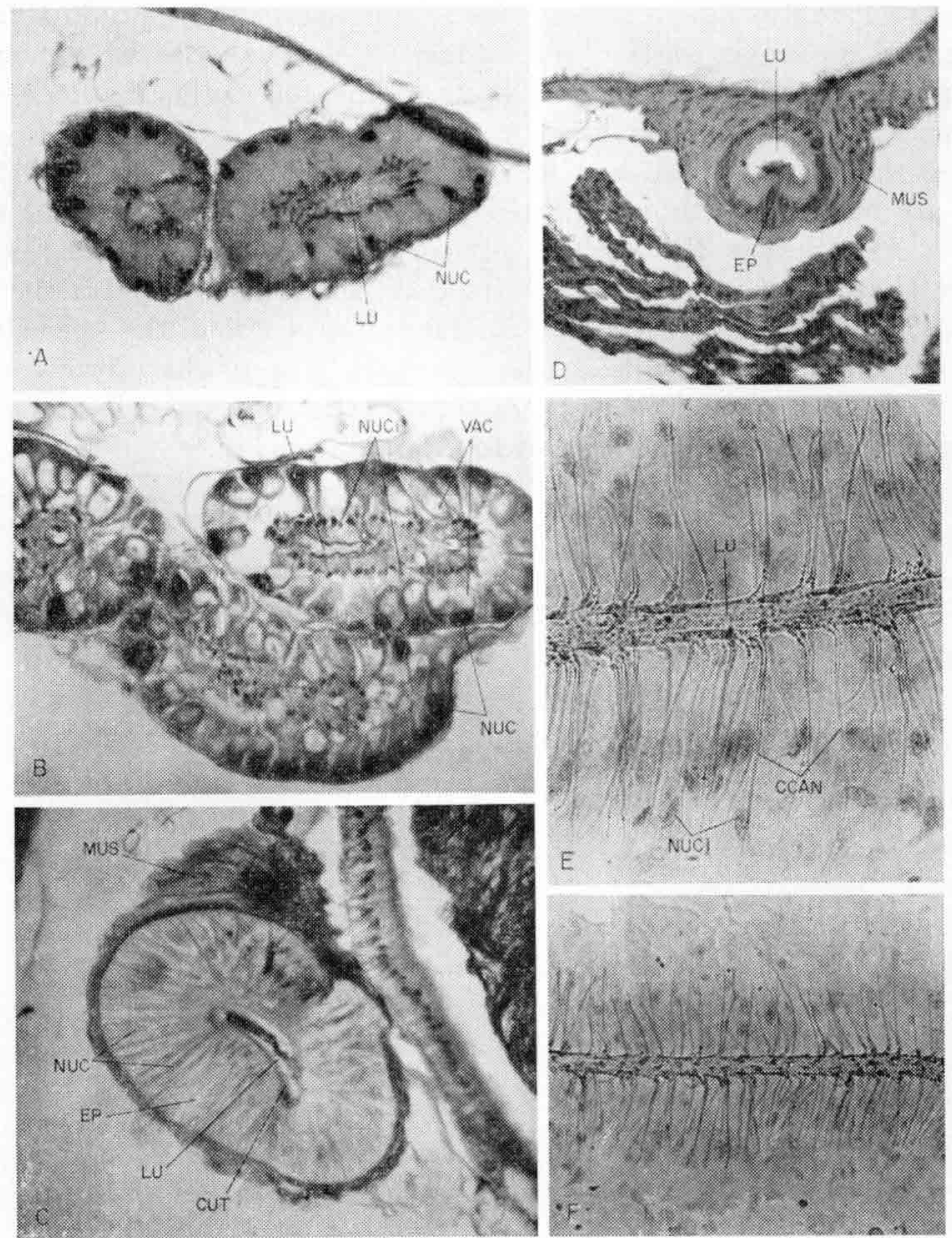

Fıg. 13. - Apis mellifica adansonii and ligustica queens

A. Longitudinal section of the spermathecal glands of a virgin queen.

B. Longitudinal section of the spermathecal glands of a mated queen, where there are secretion vacuoles.

C. Transversal section of the spermathecal duct.

D. Transversal section of the sperm pump.

$E$ and $F$. Intracellular canaliculi of the squashed spermathecal glands.

\begin{tabular}{|c|c|c|}
\hline & $=$ Epithelium & $=$ Muscles \\
\hline CCAN = & $=$ Collectory canaliculum & NUC $=$ Nucleus \\
\hline CUT & $=$ Cuticle & NUCi $=$ Intima nucleus \\
\hline LU & $=$ ¿Lumen & VAC $=$ Vacuoles \\
\hline
\end{tabular}

observations are in accordance with Woyke's and Ruttner's point of view. Membranous portions of the mating sign were within the lateral pouches of the bursa and not within the "vagina ". We use the designation genital chamber instead of " vagina " for this organ receives only the semen which will be transfered to the oviduct and afterwards to the spermatheca.

We have included the genital chamber, and the lateral pouches of the bursa 
under the general designation of bursa copulatrix, as suggested by Snodgrass (1925) and partially accepted by Laidlaw (1944).

4.1. - Genital chamber and valve-fold (fig. 14)
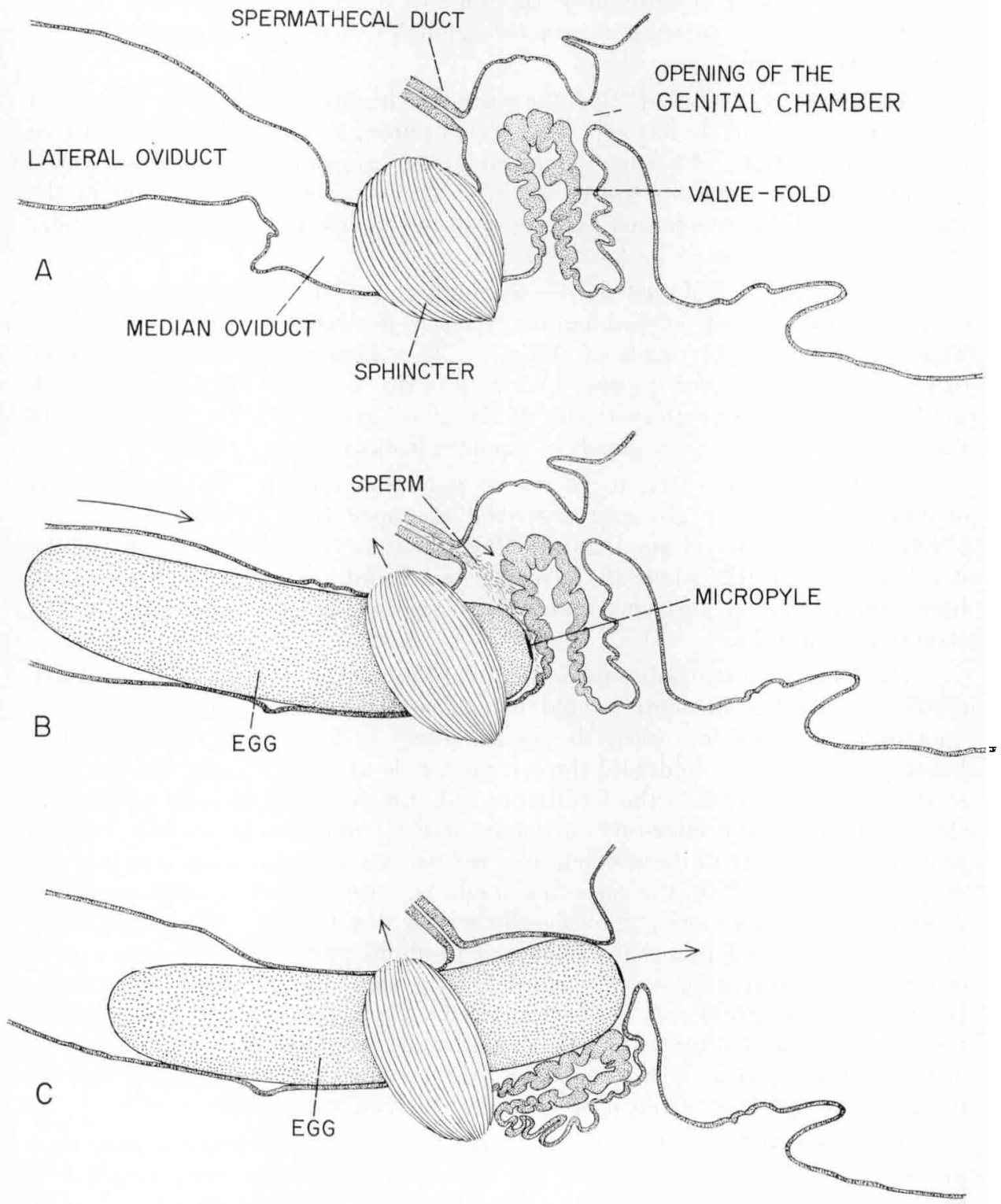

$1 \mathrm{~mm}$

Fig. 14. - Hypothetical outline of the egg fertilization and the valve-fold function

A. Original situation of the genital tract.

B. Egg fertilization. The micropyle is in contact with the valve-fold.

C. The egg exit. Explanations are in the text: 
The genital chamber was correctly described by Laidlaw (1944), who called it vagina. Our observations about anatomy and histology of the genital chamber are in accordance with LAIDLAW's investigations (1944) except in what concerns the illustrations on the general shape of the genital tract. We add some histological details, such as description of the muscles which protrude among the epithelial cells and the bursting of secretory globules in the apical portions of the cells of adult queens.

According to Losches (1916), the valve-fold begins to develop in 2-days-old pupae and is completely formed in 4-days-old pupae, although there is not a true cuticle (FYG, 1966). We have employed in our preparations 7-days-old pupae and in these the same statements apply. The occurrence of glycogen in the valve-fold, in all the ectodermal portions of the receptacle and in the sting chamber of pupae has been noted by Fyc (1966).

Both in virgin and mated queens submitted to PAS reaction, there was no positive evidence of polysaccharides except in the cuticle of the virgin queens. This cuticle is probably made of chitin. The chamber cuticle is not positive to PAS reaction in mated queens. We believe this is due to sclerotization which would reduce or eliminate reactivity of the glycol group to PAS, as reported in the cuticle of some salivary glands of Apoidea (Cruz-Landim, 1958).

According to our data, there are no polysaccharides in the chamber cells of adult queens. The glycogen described in pupae (FYG, 1966) makes clear a cellular immaturity (Cruz-Landim, 1968), because a secretory cycle will be developed in the cells where the glycogen was found. This glycogen may have been broken down to furnish the energy needed for the synthesis of plastic substances for the cells.

There has been much discussion about the function of the valve-fold. BressLau (1905) suggests this structure would fit against the orifice of the spermathecal duct to prevent suction when the sperm pump is functioning. ADAm (1913) believes that the valve-fold hold the egg micropyle against the orifice of the spermathecal duct, permitting the fertilization. LAIDLAW (1944), in spite mentioning the importance of the valve-fold during artificial insemination (it must be handled to insure the passage of the needle), does not discuss its natural function. According to Rutrner (1956), the valve-fold would be raised at rest; during copulation it would slope posteriorly, allowing the semen penetration. After copulation, the valve-fold would return to its natural position, incompletely closing genital chamber and preventing sperm escape during migration to the spermatheca. However, the valve-fold does not perform in the whole the function of preventing the sperm escape; both in artificially and naturally inseminated queens only $10 \%$ of the sperm which is deposited in the oviducts reach the spermatheca and the remainder is scattered in the sting chamber (WOYKE et al., 1966).

According to FyG (1966), both in mated and virgin queens, a degenerative process and calcification begins in the valve-fold musculature very " early " in lifetime, so that this organ loses its original flexibility. The degeneration is more prominent in 2 or 3 years-old queens. This is not an early age for queen bees; the mean longevity of a queen for beekeeping purposes is 1,5 years (KERR, 1968 -- personal communication).

Fyg (1966) disagrees with Bresslau and Adam about the loss of the initial 
mobility of the valve-fold. He believes that the valve-fold only directs the eggs from the median oviduct to the orifice of the genital chamber (= vagina opening), placing the micropyle near the spermathecal duct. He states that the valvefold partially prevent sperm escape towards the opening of the genital chamber but this observation seems not to give the whole explanation, since RUTTNER (1956) has pointed out that a great amount of sperm escapes to the sting chamber, despite the presence of the valve-fold.

In spite of our restriction to anatomical and histological field, without physiological and experimental study, we believe the valve-fold has no one single function, as suggested by Fyg, because even in an advanced calcified stage, the valve-fold shape in the genital chamber remains the same and the epithelium does not greatly change.

The egg in transversal section $(390 \mu)$ is about $1 / 3$ larger than the median oviduct $(300 \mu)$ and in longitudinal section $(1650 \mu)$ is about twice the oviduct length $(900 \mu)$ [fig. 14]. We can assume, when the egg end comes in contact with the valve-fold and the micropyle is just behind the spermathecal duct, the anterior middle portion of the egg is still within the lateral oviducts. The anterior edge of the egg is surrounded by the sphincter of the median oviduct, which prevents the egg turning upwards, as suggested by ADAM (1913).

If the micropyle is directed to the spermathecal duct, the egg would turn $90^{\circ}$ in its extremity and this probably does not happen. The median oviduct has to be greatly widened when the egg is passing through, being in a straight line in relation to the genital receptacle. Furthermore, the egg is very large when compared with the tract, and cannot turn within it. We assume that the egg, by entering the median oviduct, would be slowly strenghtened to pass through the sphincter; the semen sent forth by the spermathecal duct, would drop on the anterior surface of the valve-fold. When the egg comes in contact with this structure, there would be fecundation. The valve-fold indentations would lodge the sperm and prevent their dispersion in the tract lumen. So at the same time that the egg would be compressed against the valve-fold, the sperm reaches the micropyle. Pressure on the valve-fold would induce its turning toward the sting, allowing the genital chamber to open and permit egg passage. In other words, one function of the valve-fold would be to direct the sperm to the micropyle.

\section{2. - Oviducts}

Our observations regarding the morphological and histological structure of the lateral and median oviducts are in accordance to LAIDLAW's (1944).

The function of the musculature of the median oviduct and of the valvefold were discussed together.

\section{3. - The lateral pouches of the bursa copulatrix}

The function of these structures has not yet been clarified. According to Woyke and Rutrner (1958), the chitinized plates of the mating sign reach 
further into the bursa copulatrix of early-fecundated queens. Occasionally they find these plates within one of the two lateral pouches and sometimes within the genital chamber (= vagina). LAIDLAw (1944) has described the pouches, but did not refer to their function.

We have dissected early-fecundated queens and we find the endophallic membrane within both pouches of the bursa. These pouches are not directly related to membranous portions of the mating sign. This may suggest that the pouches would attach to the mating sign during copulation or perhaps they compress it and promote the injection of sperm into the genital chamber.

\section{4. - Spermatheca and spermathecal duct and glands}

Histological description of the spermatheca of adult queens has been performed by Bresslau (1905) and Laidlaw (1944). According to Laidlaw (1944), the cells of the spermathecal wall secrete material into the spermatheca and would be active in the exchange of gases between the spermatheca and the tracheae and in the passage of materials between the organ and the blood. We have not seen, however, any secretory process in the cells of the spermatheca epithelium, either in pupal or adult individuals.

The spermathecal duct has a heavy musculature whose function is discussed. These muscles are located where the duct contacts with the spermatheca; they are called the sperm pump (BRESSLAU, 1905) and presumably function in closing the sperm exit (Cheshire, 1884). The duct has also been claimed as being the center of a gland which secretes a fluid to separate the sperm more widely (Cheshire, 1884). Our observations show that the duct produces a protein secretion, but its function remains unknown.

Nothing about the histology of the spermathecal glands was found by us in the literature except a brief description of these organs (LaIdLAw, 1944; KaPII, 1962). The spermathecal glands are clearly secretory in mated queens. There are vacuoles which store secretion and they were found only in this stage. The intima nuclei do not play an active part in the secretory process, contrary to KaPIL's hypothesis $(1958,1962)$. When this process begins, the intima nuclei acquire a pycnotic character (Cruz-Landim \& Mello, 1968). The function of the intima cells may be related to the development of collecting canaliculi, as described in Melipona mandibular glands (Cruz-Landim \& Mello, 1967).

The collecting canaliculi react with PAS and are probably of chitinous nature, as are the canaliculi of Trigona postica mandibular glands (KerR \& Cruz-Landim, 1961; Cruz-Landim, 1963).

According to LaIDLaw (1944), the spermathecal glands secrete materials for nourishment of the sperm. In our preparations the content of the secretory vacuoles did not react as polysaccharides nor protein. We think if the secretion has the function indicated by LaIDLAw (1944), nourishment must occur when the sperm enter the duct, for the glands open into the apex of this structure, below the spermatheca. 


\section{ACKNOWLEDGEMENTS}

The authors are indebted to Dr.G. Cosenza, who furnished the Apis mellifica caucasica queens; to Dr. Edy Lello-Montenegro for some histological preparations; to Prof. Dr. W. E. Kerr for cripticism; to Dr. Miya Pereira da Silva, who kindly translated the summary to French; and to Dr. C. Michener by generous help in the English translation.

Reçu pour publication en mai 1970.

\section{ZUSAMMENFASSUNG}

\section{ANATOMIE UND HISTOLOGIE DER GESCHLECHTSWEGE UND DER SPERMATHEKA (EINSCHLIESSLICH GANG UND DRÜSEN) DER BIENENKÖNIGIN}

Die Genitalkammer, die Spermatheka sowie der Gang und die Drüsen der Spermatheka wurden mit den klassischen Methoden (Abb. 1-5) und mit dem Phasenkontrastmikroskop untersucht. Ausserdem wurden einige histochemische Reaktionen durchgeführt. Die Resultate wurden mit den schon publizierten Daten verglichen. Histologisch ergaben sich folgende Befunde :

1. Die ganze Genitalkammer und die Scheidenklappe besitzen ein einschichtiges kubisches Epithel mit einer chitinösen Cuticula aus mehreren Lamellen. Die Epithelzellen haben unregelmässige,dunkel gefärbte Kerne mit vielen Chromatinkörnchen. Das Cytoplasma ist vakuolisiert, und in den Vakuolen wird ein Sekret gespeichert, das an den apikalen Abschnitten der Zellen ent• leert wird (Abb. 6, 7, 8).

2. Sinnesorgane wurden weder an der Scheidenklappe noch an irgendeiner anderen Stelle der Genitalkammer gefunden.

3. Die Spermatheka besitzt ein einschichtiges Epithel, säulenförmig bei den Puppen und kubisch bei jungfräulichen und begatteten Königinnen. Der Zellkern begatteter Königinnen liegt in der Mitte der Zelle und hat ein pyknotisches Aussehen (Abb. 9). Das Cytoplasma zeigt immer eine positive Proteinreaktion. Im Epithel der Spermatheka wurden keine sekretorischen Vakuolen gefunden.

4. Die Spermathekaldrüsen haben ein einschichtiges sekretorisches Epithel und eine Intima. Das Epithel liegt auf einer acidophilen Basalmembran mit fusiformen Kernen (Abb. 10). Das Cytoplasma ist basophil und reagiert positiv auf Protein; die Kerne sind gross, sphärisch und basal gelegen (Abb. 10 B). Im Epithel begatteter Königinnen findet sich in grossen Vakuolen Sekret (Abb. $10 \mathrm{C}$ ). Intrazelluläre Kanälchen sammeln das Sekret und leiten es zu dem gemeinsamen Ausführungsgang. Diese Kanälchen reagieren positiv mit PAS. Die Intima ist eine amorphe cytoplasmatische Masse mit pyknotischen Kernen (Abb. 13).

Bei 7 tägigen Puppen findet man zwei Zellagen und teilweise entwickelte Sammelkanälchen (Abb. $10 \mathrm{~A})$.

5. Die "Samenpumpe " besitzt lange und eng aneinandergepresste Zellen. Die dicke Cuticula ist basophil und zaigt eine positive Reaktion auf Polysaccharide. Die Kerne sind flach und klein. Im Gegensatz zur Spermatheka findet sich im Gang ein Sekret mit Proteinkörnchen (Abb. 11).

\section{RÉSUME}

ANATOMIE ET histologie dU TRACTUS GÉNITAL, DE LA SPERMATHÈQUE, DU CANAL ET DES GLANDES DE LA SPERMATHÈQUE CHEZ LA REINE D'ABEILLE

La chambre génitale, la spermathèque, son canal et ses glandes (fig. 1 à 5) ont été étudiées par les méthodes classiques et par la microscopie en contraste de phase. Quelques réactions histochi- 
miques ont été utilisées. Les résultats ont été comparés aux travaux déjà publiés. Sur le plan histologique on a pu faire les constatations suivantes :

1. L'ensemble de la chambre génitale et de la valve vaginale est tapissé par un épithélium simple cubique avec une cuticule chitineuse plurilamellaire. Les cellules épithéliales ont des noyaux irréguliers fortement colorables par l'hématoxyline, avec de nombreux grains de chromatine. Le cytoplasme est vacuolisé et sa sécrétion est emmagasinée dans des vacuoles qui font saillie et sont éliminées par la partie apicale (fig. 6, 7 et 8 ).

2. On n'a pas trouvé d'organes sensoriels, ni sur la valve vaginale ni en aucun point de la chambre génitale.

3. La spermathèque présente un épithélium simple palissadique chez les nymphes, tandis que chez les reines vierges ou fécondes il est cubique. Le noyau des cellules des reines fécondes est central et présente un aspect picnotique (fig. 9). Le cytoplasme présente toujours une réaction protéique positive. Il n'y a pas de vacuoles sécrétrices.

4. Les glandes de la spermathèque sont constituées par un épithélium simple et par une intime. Cet épithélium repose sur une membrane basale acidophile qui présente des noyaux fusiformes (fig. 10). Le cytoplasme est basophile et réagit de façon positive aux réactifs spécifiques des protéines. Les noyaux sont grands, sphériques et placés au centre (fig. $10 \mathrm{~b}$ ). Chez les reines fécondes la sécrétion est emmagasinée dans de grandes vacuoles et les noyaux prennent une position basale (fig. $10 \mathrm{c}$ ). Des canalicules intra-cellulaires collectent la séerétion; ils réagissent positivement au PAS; ils conduisent la secrétion jusqu'à la lumière des glandes. L'intime est une masse cytoplasmique amorphe à noyaux picnotiques. Chez les nymphes de 7 jours, on remarque deux couches de cellules et des canalicules sécréteurs partiellement développés (fig. $10 \mathrm{a}$ ).

5. La " pompe à sperme " est tapissée par un épithélium où les cellules sont serrées les unes contre les autres. On y note une cuticule basophile épaisse qui présente une réaction positive aux polysaccharides. Les noyaux sont plats et petits.

Contrairement à la spermathèque, on trouve dans le canal une sécrétion à graines protéiques (fig. 11).

\section{REFERENCES}

AdAM'A., 1913. Bau und Mechanismus des Receptaculum seminis bei den Bienen, Wespen und Ameisen. Zool. Jb., Abt. Anat. Ontog. Tiere, 35, 1-74.

Bresslau E., 1905. Der Samenblasengang der Bienenkönigin. Zool. Anz., 29, 299-323.

Camargo J. M. F., Gonçalves L.S., 1968. Note on techniques for instrumental insemination of queen honey bees. J. Apic. Res., 7, (3), 157-161.

Cheshire F. R., 1884. Recent investigations into the structure of the egg organs of the queen. Beekeep. Magaz., 12, 310-313.

CRUz-Landim C., 1967. Estudo comparativo de algumas glândulas das abelhas (Hym., Apoidea) e respectivas implicações evolutivas. Arqu. Zool. S. Paulo, 15 (3), 177-2 ऽo.

Cruz-Landim C., 1968. Histoquímica e ultraestrutura das glandulas salivares das abelhas (Hym., Apoidea) Arqu. Zool. S. Paulo, 17, (3), 113-166.

Cruz-Landim C., Kitajima E. W., 1966. Ultraestrutura do aparelho venenifero de Apis (Hym., Apidae). Mem. Inst. Butantz̃, 33, (3), 701-710.

Cruz-Landim C., Mello M. L. S., 1967. The Post-Embryonic Changes in Melipona quadrifasciata anthidioides Lep. (Hym. Apoidea). II- Development of the salivary glands system. J. Morph., $123,(4), 481-502$.

Cruz-Landim C., 1969. Development of polyploidy in silk glands of Melipona quadrifasciata anthidioides Lep. (Hym., Apoidea) during the larval stage. J. Exper. Zool., 170, (2), 149-156. 
Fresnaye J., 1966. L'insémination artificielle des reines d'Abeilles. Ann. Abeille, 9, (3), 251-263.

Fyg W., 1966. Ueber den Bau und die Funktion der Valvula vaginalis der Bienen-königin (Apis mellifica L.). Z. Bienenforsch., 8, (8), 256-266.

Hunter J., 1792. Observations on bees. Philos. Trans. Roy. Soc. London., 82, 128-195.

KAPIL R. P., 1958. Morphology and histology of the salivary gland system of honeybee, Apis Indica. Arch. Bienenkde, 35, 17-22.

KapIL R. P., 1962. Anatomy and Histology of the Female Reproductive System of Apis indica F. (Hym.. Apidae). Insectes sociaux, 9, (2), 145-163.

Kerr W. E., Cruz-Landim C., 1961. Funções diferentes tomadas pela glândula mandibular na evolução das abelhas em geral e em Trigona (Scaptotrigona) postica em especial. Rev. Brasil. Biol., 21, (1), 1-16.

LaIDLAw Jr. H. H., 1944. Artificial insemination of the queen bee (Apis mellifera L.). Morphological basis and results. J. Morph., 74, 429-465.

Loschel F., 1916. Die postembryonale Entwicklung des Geschlechtsapparates der Bienenkönigin (Apis mellifica L.). Z. angew. Entomol., 3, 21-44.

Mackensen O., Roberts C., 1948. A manual for the artificial insemination of queen bees. U.S.D.A. Bur. Entomol. and Plant Quarant. - 250.

Nelson J. A., 1915. The Embryology of the Honey Bee. Princeton Univ. Press, Princeton. 282 p.

NoLAN W. J., 1932. Breeding the honeybee under controlled conditions. U.S.D.A. Tech, Bull. - 326.

NoLaN W. J., 1937 a. Bee breeding. U.S.D.A. Yb., 1396-1418.

Nolan W. J., $1937 b$. Improved apparatus for inseminating queen bees by the Watson method. J. Econ. Entomol., 30, 700-705.

Pearse A. G. E., 1961. Histochemistry Theoretical and Applied. J. \& A. Churchill Ltd., London. $\mathrm{x}-998 \mathrm{p}$.

RutTNER F., 1956. Zur Frage der Spermaubertragung bei der Bienenkönigin. Insectes Sociaux, $3,351-359$.

Snodgrass R. E., 1925. Anatomy and physiology of the Honeybee. McGraw-Hill, New York.

Snodgrass R. E., 1956. Anatomy of the Honey Bee. Comstock Publ. Assoc., Ithaca, N. Y. XIV $334 \mathrm{p}$.

Swammerdan J., 1758. The book of nature; or the history of insects : Reduced to distinct classes, confirmed by particular instances, displayed in the anatomical analysis of many species. (English Translation from the Dutch and Latin original editions by Thomas Floyd. Revised and improved by John Hill. London).

Watson L. R., 1927. Controlled mating of queen bees. Publ. as pamphlet by American Bee Journal, Hamilton, IH., 50 p Condensed in Amer. Bee J., 67, 235-236; 300-302; 364-365.

Woyke J., 1967. Rearing Conditions and the Number of Sperm Reaching the Qusens Spermatheca. Apimondia XXI intern. Beekeep. Congress, 84.

Woyke J., Rutrner F., 1958. An Anatomical Study of the Mating Process in the Honeybee. Bee World, 39, (1), 3-18.

Woyke J., Ruttner F., and Vesely V., 1966. Manual on Artificial Insemination of the Queen Bees. Intern. course on the artificial insemination, $132 \mathrm{p}$.

\section{Address :}

João M.F. de CAMARGO \& M.L.S. MELLO

Departamento de Genética

Faculdade de Medicina de Ribeirão Prêto

Caixa Postal, 301

Ribeirão Prêto, S.P., Brésil 